\title{
Aerodynamic and Stability Analysis of the Safat01 Aircraft
}

\author{
Rania Qurashi ${ }^{1)}$ \\ Mohmmed Alhadi ${ }^{2}$ \\ Sakher Abudarag ${ }^{1)}$ \\ Dragoljub Vujic ${ }^{3}$
}

\begin{abstract}
This paper aimed to predict aerodynamic \& stability data for the Safat01 aircraft. Because of its economic and time efficiency, the Digital DATCOM program has been used to predict the stability and control derivatives for the subsonic, low angle of attack (less than 15 degrees) flight regimes. The DATCOM aerodynamic results were very close when compared to CFD. The effect of the nominal centre of the gravity position was considered. According to the computed stability results, the aircraft has been found statically stable and possessing longitudinal dynamic stability. This agrees with the flight tests results conducted on the aircraft which showed stable behaviour.
\end{abstract}

Key words: light aircraft, subsonic aircraft, aerodynamic characteristics, aircraft stability, stability derivatives, static stability, dynamic stability, stability analysis.

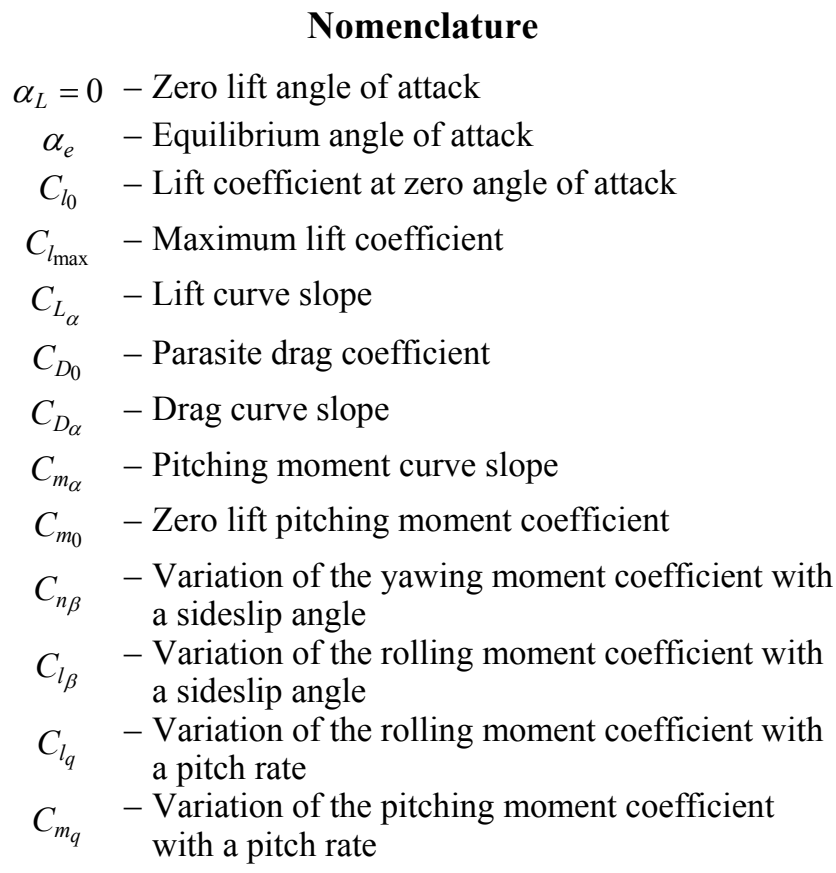

\section{Introduction}

$\mathrm{T}$ HIS research targets to perform an aerodynamic analysis of the Safat01 aircraft (Fig.1). It involves determining the aerodynamic qualities of the aircraft. Digital DATCOM has been chosen to be a design tool of the Safat01 to estimate the aerodynamic data and stability derivatives. In addition to money and time saving, the results of DATCOM at low speed are close to wind tunnel tests and usually provide an acceptable level of accuracy [1].

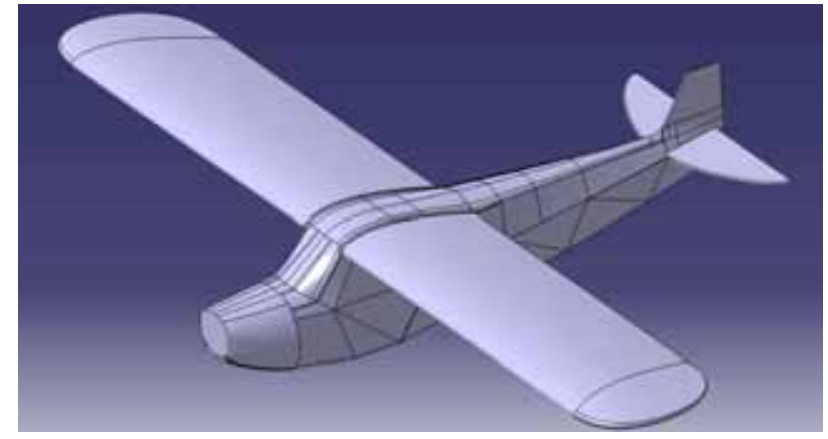

Figure 1. Safat01 aircraft

\section{Safat01 aircraft specifications}

The Safat01 is a light, single-engine, monoplane aircraft with a high - strut - braced wing of the USA 35B airfoil section. It is used for primary training, and has the following specifications given in Table 1, Table 2 and Table 3.

Table 1. Technical data of the Safat01 aircraft [3]

\begin{tabular}{|c|c|}
\hline Gross weight $(\mathrm{kg})$ & 680 \\
\hline Length $(\mathrm{m})$ & 6.8 \\
\hline Height $(\mathrm{m})$ & 1.9 \\
\hline Stall speed $(\mathrm{km} / \mathrm{h})$ & 40 \\
\hline Centre of gravity location $(\mathrm{m})$ & $1.74($ from the aircraft nose) \\
\hline Ceiling $(\mathrm{m})$ & 300 \\
\hline Aspect ratio & 7 \\
\hline
\end{tabular}

Table 2. Geometry of the Safat01 aircraft [2]

\begin{tabular}{||c|c|c|c||}
\hline \hline Description & Wing & Horizontal tail & Vertical tail \\
\hline Area $\left(\mathrm{m}^{2}\right)$ & 16.6 & 1.477 & 0.4329 \\
\hline Root chord $(\mathrm{m})$ & 1.6 & 0.68 & 0.72 \\
\hline Span $(\mathrm{m})$ & 10.74 & 2.88 & 1.354 \\
\hline Incidence $($ deg.) & 2 & 0.0 & 0.0 \\
\hline Dihedral (deg.) & 0.0 & 0.0 & 0.0 \\
\hline
\end{tabular}

\footnotetext{
1) Sudan University of Science and Technology, P.O.Box. 407, Khartoum, SUDAN

2) Karary University, Aeronautical Research Centre, P.O.Box. 13342, Khartoum, SUDAN

3) Military Technical Institute (VTI), Ratka Resanovića 1, 11132 Belgrade, SERBIA

Correspondence to: Rania Qurashi; e-mail: rania7885@yahoo.com
} 
Table 3. USA 35B airfoil geometry [3]

\begin{tabular}{|c|c|}
\hline Thickness (percentage of chord) & $11.6 \%$ \\
\hline Maximum camber (percentage of chord) & $3.2 \%$ \\
\hline Leading edge radius (percentage of chord) & $3.5 \%$ \\
\hline Trailing edge angle (deg) & 11.4 \\
\hline Lower flatness (percentage of chord) & $94.2 \%$ \\
\hline
\end{tabular}

\section{Aerodynamic and static stability results}

The aerodynamic and static stability derivatives results are displayed in Table 4.

Table 4. Aerodynamic and static stability results

\begin{tabular}{|c|c|c|}
\hline Parameter & DATCOM result & CFD result [4] \\
\hline \hline$C_{l_{0}}$ & 0.469 & 0.487 \\
\hline$C_{l_{\max }}$ & 1.69 & 1.67 \\
\hline$C_{L_{\alpha}}$ & 0.09 & 0.09 \\
\hline$\alpha_{L}=0$ & -5.5 & -5.45 \\
\hline$C_{D_{0}}$ & 0.026 & 0.035 \\
\hline$C_{D_{\alpha}}$ & 0.28 & 0.25 \\
\hline$C_{m_{\alpha}}$ & -0.0138 & -0.0185 \\
\hline$C_{m_{0}}$ & 0.0577 & 0.042 \\
\hline$\alpha_{e}$ & 1.5 & 1.2 \\
\hline$C_{n_{\beta}}$ & 0.0006 & 0.00072 \\
\hline$C_{l_{\beta}}$ & -0.00132 & -0.005 \\
\hline$C_{l_{q}}$ & 0.075 & 0.0005 \\
\hline$C_{m_{q}}$ & -0.1062 & -0.00129 \\
\hline
\end{tabular}

\section{Aerodynamic calculations}

\section{Lift}

The lift varies linearly with the angle of attack till it equals 15 degrees - where the lift coefficient reaches its maximum value the stall begins and the non-linearity appears due to flow separation. The value of the lift coefficient at zero angle of attack is 0.469 and the maximum lift coefficient is 1.69 ; the two values are the same for DATCOM and CFD. The DATCOM result is shown in Fig.2. The ground effect on the lift coefficient is to increase lift when the wing is near the ground and takes advantage of the favorable interaction between the wing and the ground. When the ground factor (wing height above ground/wing span) is near the ram value of 0.1 , the ground effect is too high because the wing is very close to the ground and the trailing edge creates a sealed envelope and modifies the pressure field. The effect is decreased as the aircraft is far away from the ground; the lift variation with the ground effect is given by DATCOM and shown in Fig.3.

\section{Centre of pressure movement}

The centre of pressure does not occupy a fixed location. As the angle of attack is changed, the pressure at each point on the airfoil changes. Therefore, the location of the centre of pressure changes as well. The centre of pressure moves forwards as the angle of attack increases.

However, at the point of stall, the centre of pressure moves quickly backwards, causing a nose down pitching moment. The result is obtained by DATCOM and shown in Fig.4. When the lift coefficient is zero, an airfoil generates no lift but a conventionally cambered airfoil generates a nose-down pitching moment, so the location of the centre of pressure is an infinite distance behind the airfoil.

\section{Drag}

The drag varies with the angle of attack linearly till the stall angle of attack because of its dependency on lift. After the stall angle of attack, the drag coefficient keeps rising due to flow separation. The variation of drag coefficients with the angle of attack is the same for DATCOM and CFD and equals 0.28 per deg. The various parts contributions to the drag coefficient are shown in Fig.5, from where it is obvious that the wing is the main contributor. The ground effect is to decrease drag by decreasing the induced drag, when the wing is in the area of the ground effect due to a part elimination of wing tip vortices. The variation of the drag coefficient with the ground effect obtained by DATCOM is in Fig.6.

\section{Stability results}

\section{Longitudinal static stability}

The results obtained from DATCOM show a positive longitudinal stability according to the stability criteria. The value of zero lift moment about the centre of gravity 0.0577 is positive quantity and the moment's curve slope is negative and equals 0.0138 , which satisfies the longitudinal static stability conditions. The main contributor to longitudinal static stability is the horizontal stabilizer by the largest positive value to balance the pitch down caused by the wing and other aircraft parts. The value of the moment curve slope is within the range for most aircraft, between - 0.3 to -1.5 per rad [5]. The obtained results and various aircraft parts contributions are shown in Fig.7.

\section{Directional static stability [9]}

The aircraft showed stable behaviour in directional stability. The value of $c_{n_{\beta}}$ equals the desirable value obtained (0.00057) and close to that of CFD.

\section{The effect of the centre of gravity location on longitudinal} stability [10]

The effect of the movement of the centre of gravity towards the trailing edge on longitudinal static stability is to increase the zero lift moment coefficient and decrease the moment curve slope due to the reduction in the static margin. The trim angle of attack of the aircraft increases with the centre of gravity (c.g.) forward shift. The moment curve became approximately flat with the movement of the centre of gravity towards a neutral point. The rate of the change of the pitching moment coefficient with respect to the pitch rate decreases with the centre of gravity forward shift; it is directly affected by static margin reduction. The larger the negative value of $C_{m_{q}}$, the higher a stabilizing impact on longitudinal dynamic stability. The values of $C_{m_{q}}$ for the whole centre of gravity range are within the range. For most aircraft, it is between - 0.087 to 0.523 per deg [5] and the rate of change of the rolling moment coefficient with pitch is also reduced as demonstrated in Fig.10. All these results are demonstrated in Table 5. The whole studied centre of gravity range showed that nominal locations from $23 \%$ to $28 \%$ are permissible (Fig.8), because the stability criterion is still satisfied and $C_{m_{q}}$ is also within the typical value for most aircraft.

Table 5. Effect of the movement of the centre of gravity (c.g) on longitudinal stability

\begin{tabular}{|c|c|c|c|c||}
\hline Centre of gravity location & $C_{m_{0}}$ & $\alpha_{e}(\mathrm{deg})$ & $C_{m_{q}}$ & $C_{l_{q}}$ \\
\hline \hline $23 \%$ & 0.0577 & 1 & -0.1059 & 0.0752 \\
\hline $24 \%$ & 0.0586 & 1.25 & -0.1049 & 0.07382 \\
\hline $25 \%$ & 0.0592 & 2 & -0.1038 & 0.07238 \\
\hline $26 \%$ & 0.0599 & 2.25 & -0.1028 & 0.07094 \\
\hline $27 \%$ & 0.0606 & 3 & -0.1018 & 0.0694 \\
\hline $28 \%$ & 0.0612 & 3.5 & -01009 & 0.06805 \\
\hline
\end{tabular}




\section{Longitudinal dynamic results}

For the specific aircraft parameters, the longitudinal dynamic roots are

$$
\begin{gathered}
S_{1,2}=-6.1384 \pm 14.3744 i \\
S_{3,4}=0.0216 \pm 0.2602 i
\end{gathered}
$$

The roots are complex pairs, which indicates that the response is periodic. The real part is negative, which means that the amplitude of the periodic variation will decrease with each oscillation (the damped mode). This type of motion is called subsidence [6]. The first couple of roots indicates a short period oscillation (SPO) with heavy damping. In this period, the angle of attack and the pitch rate change rapidly whereas the velocity remains approximately constant. Within this short time, the angle of attack is nearly restored to its initial undisturbed value and remains so thereafter.

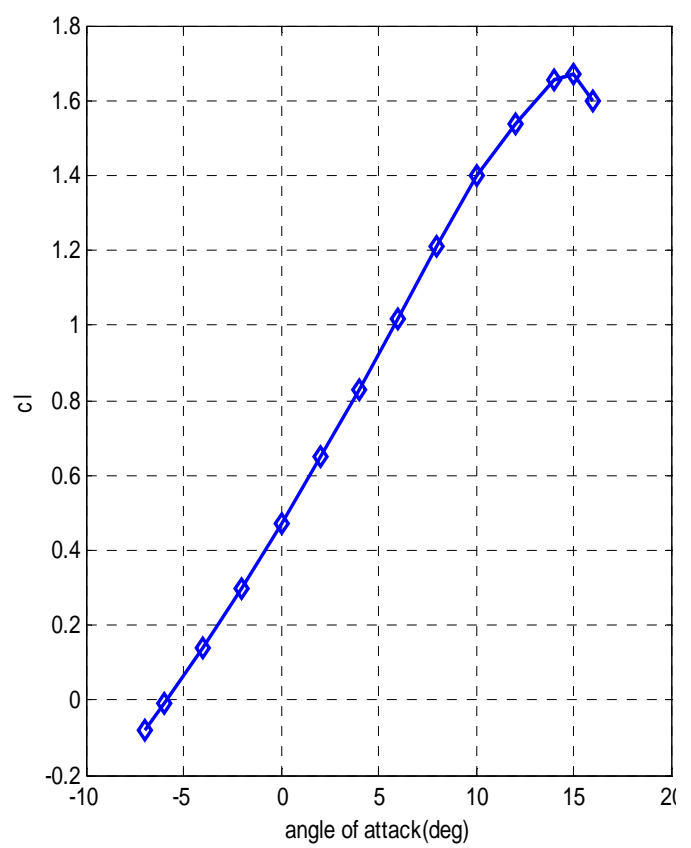

Figure 2. Variation of the lift coefficient with the angle of attack

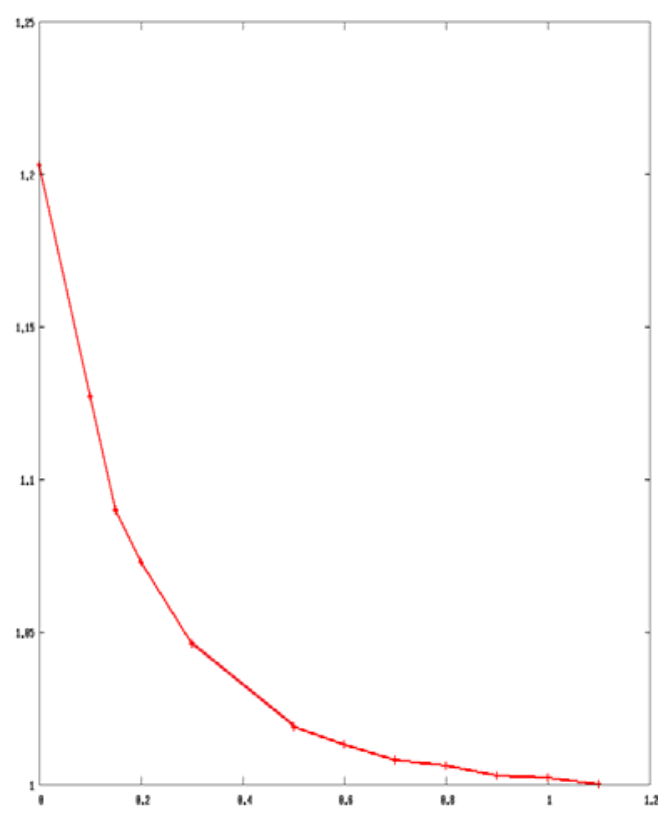

Figure 3. Change in lift due to the ground effect
The second couple of roots indicates a long period \& low damping (long period oscillation). In the long period oscillation, there are changes in velocity while the angle of attack remains almost constant. The long period oscillation persists after the SPO has died down and influences the changes in velocity while the angle of attack remains almost constant. The total energy of the aircraft is nearly constant during this motion and there is an exchange between the kinetic energy and the potential energy of the aircraft. As the flight speed decreases, the aircraft loses kinetic energy and gains potential energy. It reaches a crest when the velocity is minimal. Conversely, when the velocity increases, the altitude decreases and the flight path shows a minimum value with the maximum velocity.

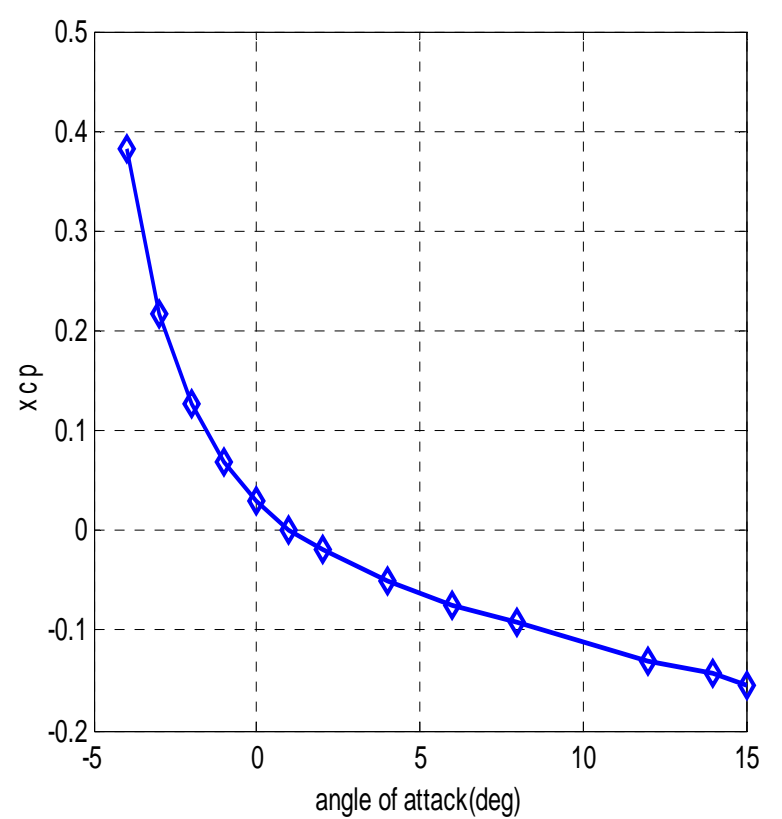

Figure 4. Variation of the centre of pressure (cp) location with the angle of attack

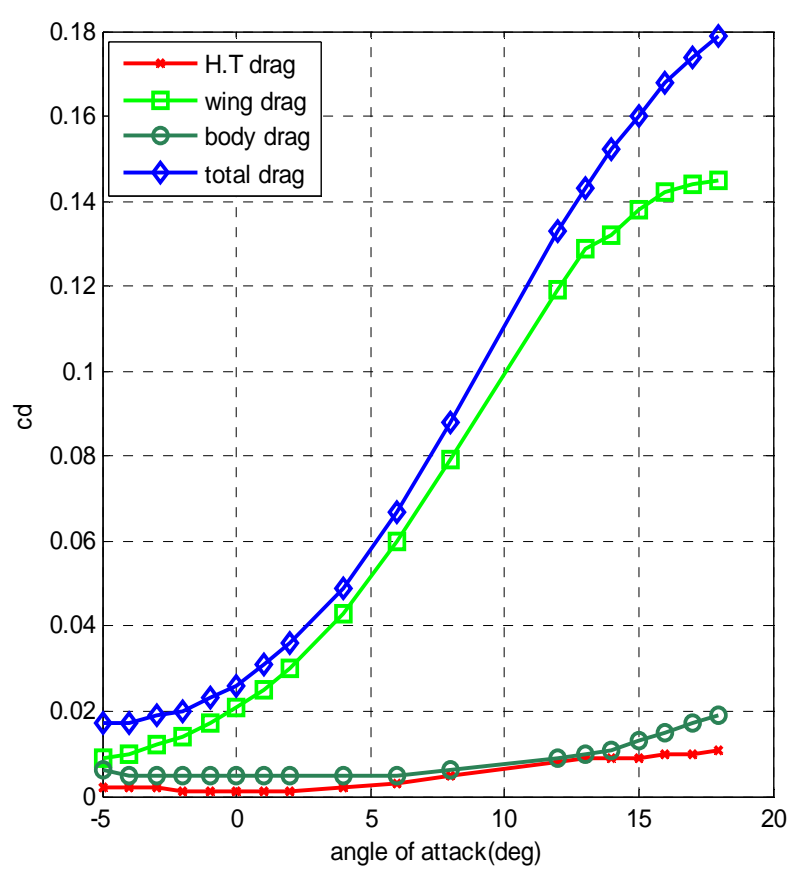

Figure 5. Drag coefficient variation with the angle of attack 


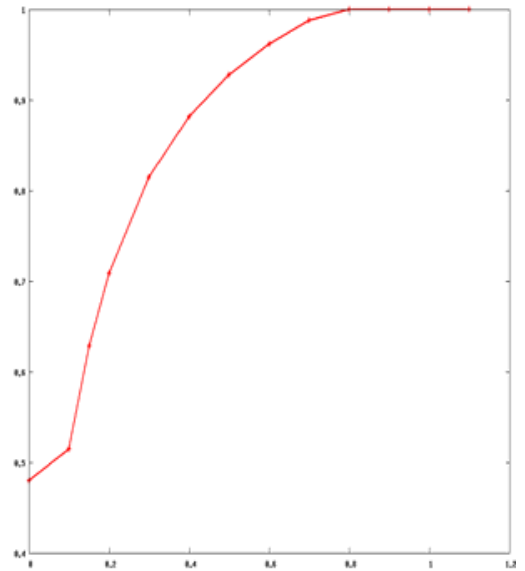

Figure 6. Change in drag due to the ground effect

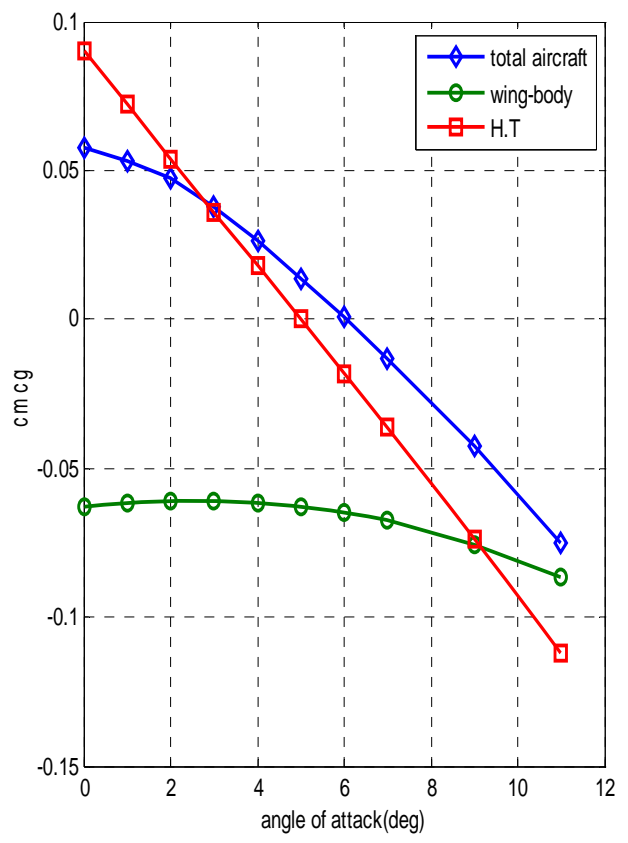

Figure 7. Variation of the pitching moment coefficient with the angle of attack and the contributions of various parts

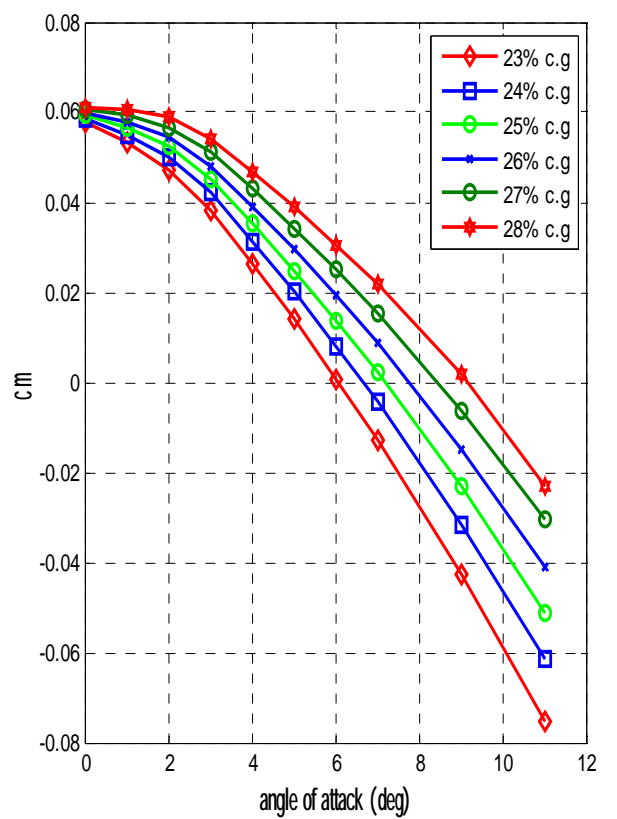

Figure 8. Effect of the centre of gravity location on the pitching moment coefficient

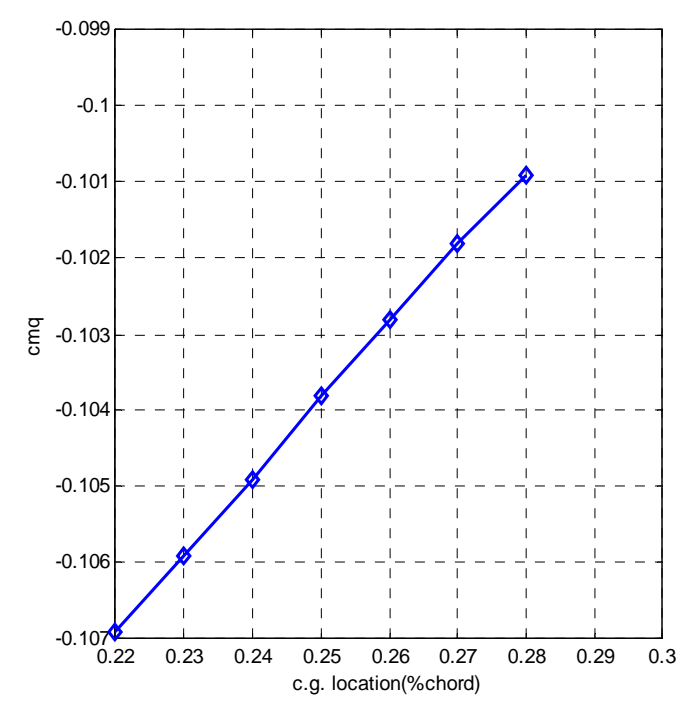

Figure 9. Pitch damping variation with the centre of gravity location

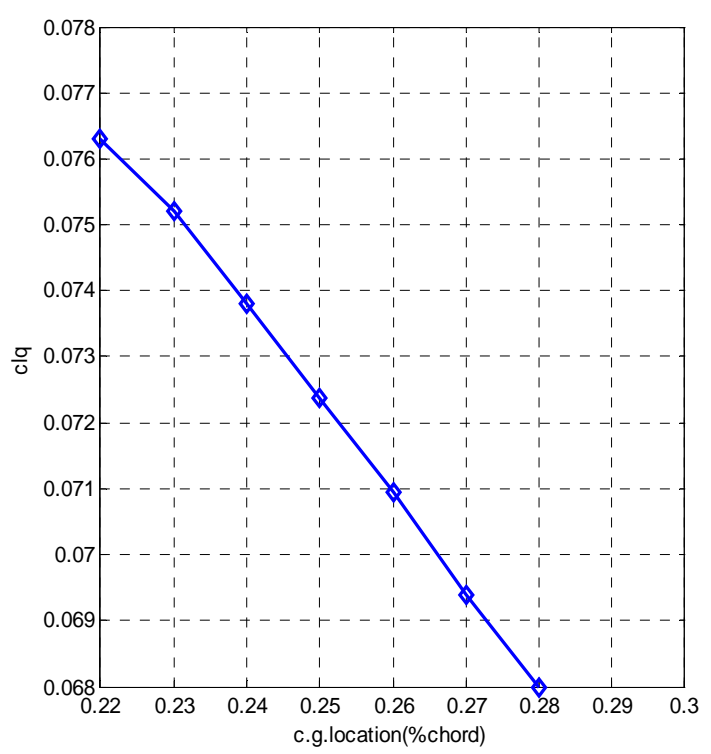

Figure 10. Variation of the rolling moment coefficient change with pitch rate with the centre of gravity location

\section{Conclusion}

The DATCOM program has been used to estimate the stability and control derivatives for the subsonic, low angle of attack (less than 15 degrees) flight regimes for the Safat01 aircraft. The resulted stability and control derivatives have been used to estimate the aircraft longitudinal dynamic stability. According to the computed stability results, the aircraft has been found statically and dynamically (longitudinally) stable. This, however, agrees with the flight tests results conducted on the Safat01aircraft which showed stable behaviour $[7,8]$.

\section{Recommendations}

Although this research has identified a data generation technique, to assure stability and controllability in the ranges of low angles of attack, the following research is still needed:

- Improving the accuracy results by other techniques to reinforce the obtained results and enhance the accuracy.

- Effects of aeroelasticity should be taken into account $[11,12,13]$. 


\section{Literatura}

[1] BLAKE,W.B.: Missile DATCOM: User's Manual-1997 FORTRAN 90 Version, Air Force Research Laboratories, Document AFRL-VAWP-TR-1998-3009, Feb. 1998.

[2] AERODYNAMICS GROUP, Sudan master technology, Aeronautical research centre, Piper Aircraft data.

[3] http://www.worldofkrauss.com/foils/1061: „Airfoil data” retrieved May 10,2011

[4] MAHADI,M.: Computational aerodynamic analysis of a light aircraft, MSc dissertation, Karary University, 2012.

[5] ROSKA,M: Aircraft Flight Dynamics and Automatic Control, Darcorp 1998.

[6] NELSON: Flight stability and automatic control, McGraw-Hill, 1989.

[7] Safat01 flight test report 2012.

[8] QURASHI,M.R., ALHADI,M., ABUDARAG,S.: Aerodynamic and stability considerations of Safat01, $6^{\text {th }}$ International Scientific Conference on Defensive Technologies, OTEH 2014, Belgrade, Serbia, 9-10 October 2014, Proceedings, pp.119-122.

[9] THOMAS,R.Y:: Introduction to Aircraft Flight Mechanics: Performance, Static Stability, Dynamic Stability, and Classical
Feedback Control, American Institute of Aeronautics\&Astronautics, 2003.

[10] GARIMA,C., ANIRUDH,K., VISHAL,S., SHIKHA,K., SUDHIR,K.C.: A Comparative Study of Aircraft Controlling Surfaces: Defence and Commercial Applications, International Journal of Engineering Research and Applications (IJERA), ISSN:2248-9622, National Conference on Advances in Engineering and Technology, $29^{\text {th }}$ March 2014, pp.61-65.

[11] STEFANOVIC,Z., KOSTIC,I., KOSTIC,O.: Determination of Aerodynamic Characteristics of A Light Aircraft Using Viscous CFD Modeling, Machine Design, 2014, Vol.6, No.3, pp.71-78.

[12] MAKSIMOVIC,S., VASOVIC,I., MAKSIMOVIC, M.,.DJURIC,M.: Some Aspects of the Damage Tolerance Analysis of the LASTA Training Aircraft Structures, Scientific Technical Review, ISSN 18200206, 2013, Vol.63, No.2, pp.70-74.

[13] DIMITRIJEVIC,J., KOVACEVIC, P.: Computational Modal Analysis of the LASTA Aircraft, Scientific Technical Review, ISSN 1820- 0206, 2010, Vol.60, No.2, pp.60-69.

\title{
Aerodinamička analiza i analiza stabilnosti aviona Safat01
}

Ovaj rad imao je za cilj da odredi aerodinamičke karakteristike i stabilnost aviona Safat01. Iz ekonomskih razloga i uštede u vremenu, za određivanje derivativa stabilnosti i upravljanja za podzvučne režime leta i male napadne uglove - manje od 15 stepeni korišćen je program Digital DATCOM. Aerodinamički rezultati dobijeni ovim programom bili su veoma bliski rezultatima CFD analize. Razmatran je efekat nominalnog položaja centra mase. U skladu sa sračunatim rezultatima stabilnosti, nađeno je da je avion statički stabilan i da poseduje uzdužnu dinamičku stabilnost. To se slaže sa rezultatima letnih ispitivanja tokom kojih je avion pokazao stabilno ponašanje.

Ključne reči: laki avion, podzvučni avion, aerodinamičke karakteristike, stabilnost aviona, derivativi stabilnosti, statička stabilnost, dinamička stabilnost, analiza stabilnosti.

\section{Аэродинамический анализ и анализ стабильности самолёта Safat01}

\begin{abstract}
Цель этого исследования была, определить аэродинамические характеристики и стабильность самолёта Safat01. По экономическим причинам и из-за экономии времени, чтобы определить производные стабильности и управление для дозвуковых режимов полёта и малых углов атаки - меныше чем 15 градусов, используется цифровая программа DATCOM. Аэродинамические результаты, полученные с помощью этой программы, были очень близки к результатам анализа CFD. Мы рассмотрели влияние и эффективность номинального положения центра массы. В соответствии с результатами расчётов по стабильности было обнаружено, что самолёт по статической плоскости устойчив и имеет и продольную динамическую устойчивость. Это согласуется с результатами лётных испытаний, в течение которых самолёт показал стабильное поведение.
\end{abstract}

Ключевые слова: лёгкий самолет, дозвуковой самолёт, аэродинамические характеристики, стабильность самолёта, производные стабильности, статическая устойчивость, динамическая устойчивость, анализ устойчивости.

\section{Analyse d'aérodynamique et de stabilité de l'avion Safat01}

Le but de ce travail était de déterminer les caractéristiques aérodynamiques et la stabilité de l'avion Safat01. Pour des raisons économiques et pour épargner le temps on a utilisé le programme digital DATCOM afin de déterminer les dérivatifs de stabilité et de contrôle chez les régimes subsoniques de vol ainsi que pour les petites angles d'attaque inférieures à 15 degrés. Les résultats aérodynamiques obtenus à l'aide de ce programme sont très proches aux résultats obtenus par l'analyse CFD. On a considéré l'effet de la position du centre de masse. Selon les résultats calculés de stabilité on a constaté que l'avion était stable statiquement et qu'il possédait une dynamique longitudinale stable. Cela est en bon accord avec les résultats des essais en vol au cours desquels l'avion a démontré un stable comportement. 